\section{Rhabdomyolysis and acute renal failure in sickle cell anaemia}

Acute renal failure due to striated muscle necrosis is well recognised in a wide range of conditions. ${ }^{1}$ This report concerns a patient with homozygous sickle cell disease, in whom acute renal failure was associated with rhabdomyolysis during a severe sickling episode.

\section{Case report}

A 25 year old Nigerian man presented with a three day history of a painful right knee, abdominal pain, diarrhoea, vomiting, and fever. Previously healthy, he had been admitted to hospital only once before suffering from sickle cell crisis.

Examination showed he was drowsy but well orientated. His temperature was $38.5 \mathrm{C}$ and he was moderately dehydrated with a blood pressure of $110 / 70 \mathrm{~mm} \mathrm{Hg}$, both erect and supine. The heart and lungs were normal. There was some upper abdominal tenderness on the right side but no signs of neritonism and normal bowel sounds. The right knee was clinically normal and there were no focal neurological signs. Haemoglobin was $6.4 \mathrm{~g} / \mathrm{dl}$, white cell count $11.3 \times 10^{9} / 1$ with $92 \%$ neutrophils. Radiographs of the chest, abdomen, and right knee showed no abnormality.

Sickle cell crisis with possible biliary and bone sepsis was diagnosed, and he was given intravenous rehydration, penicillin, gentamicin, and analgesia. Six hours later his condition had deteriorated with persistent fever, confusion, and tachypnoea. There was pronounced right upper abdominal tenderness with reduced bowel sounds and signs of peritonism.

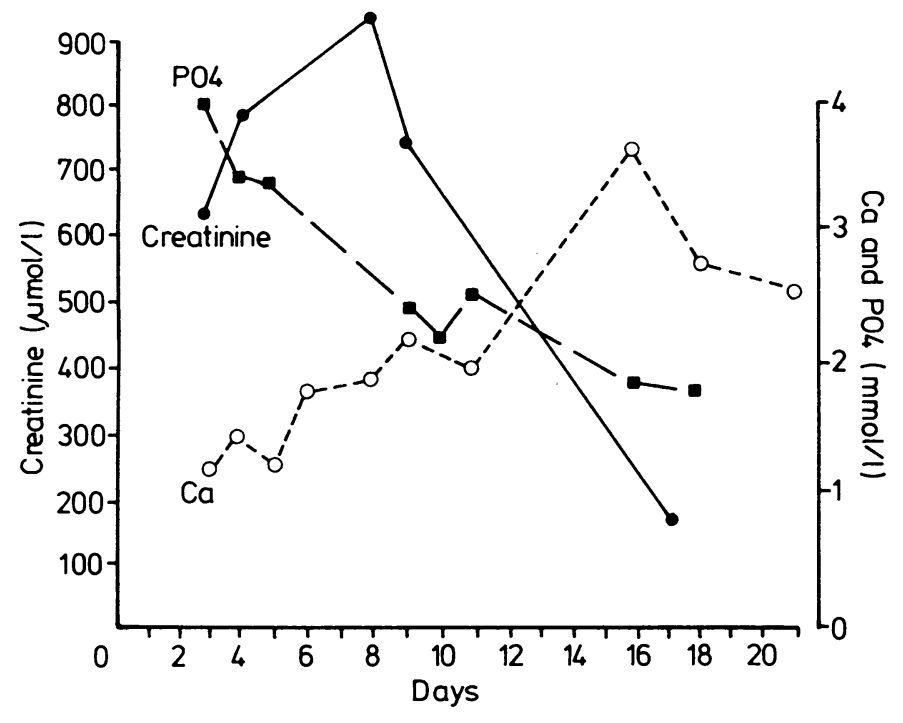

Serial changes in plasma creatinine, calcium, and phosphate.

No urine output had been charted since admission, and a urinary catheter was passed, producing a small volume of dark urine which contained blood and protein. Microscopy showed scanty red cells, but insufficient urine prevented further analysis. Blood urea was $21 \mathrm{mmol} / 1(127 \mathrm{mg} / 100 \mathrm{ml})$, potassium $3.0 \mathrm{mmol}(\mathrm{mEq}) / 1$, bicarbonate $21 \mathrm{mmol}(\mathrm{mEq}) / 1$, blood $\mathrm{pH} 7 \cdot 31$, $\mathrm{PCO}_{2} 2.6 \mathrm{kPa}(19.5 \mathrm{~mm} \mathrm{Hg}), \mathrm{Po}_{2} 14.2 \mathrm{kPa}(107 \mathrm{~mm} \mathrm{Hg})$, and blood glucose $8.0 \mathrm{mmol} / \mathrm{l}(144 \mathrm{mg} / 100 \mathrm{ml})$. Serum urate concentration was not measured.

An ultrasound scan of the abdomen showed multiple gall stones and a thickened gall bladder wall with fluid around the gall bladder bed, indicating possible gall bladder empyema and perforation. Antibiotics were modified to cover biliary pathogens including salmonellae. An exchange transfusion was performed to prevent further sickling. The patient's general condition precluded surgery.

Renal function rapidly deteriorated and haemodialysis was started. Subsequently, both blood and stool cultures revealed a group D salmonellae species. Creatine kinase activities were greater than $500000 \mathrm{U} / 1$ (normal $<500 \mathrm{U} / \mathrm{l}$ ). Laparotomy three days later showed an inflamed but intact gall bladder and a gangrenous segment of small bowel, which was resected. Renal function improved although hypercalcaemia developed during the recovery phase (see figure).

After operation the patient's fever resolved by lysis, and antibiotics were stopped 14 days after admission. Three days later a high swinging fever developed, and he had a fluctuant mass over the lower medial aspect of the right femur. Radiographs of the femur showed osteomyelitis, and $250 \mathrm{ml}$ of sterile purulent material was drained from a subperiosteal abcess. A prolonged course of antibiotics completely resolved this problem, and the patient was discharged from hospital in good health 12 weeks after admission.

\section{Comment}

Exacerbation of sickle cell anaemia is precipitated by infection, dehydration, and hypoxaemia. The most common clinical symptoms are bone and abdominal ischaemic pain, due to microvascular occlusion by sickled cells, although any organ system may be affected. Other renal problems include haematuria due to papillary necrosis, water loss due to chronic nephropathy, nephrotic syndrome, and chronic renal failure. ${ }^{2}$ Acute renal failure does not seem to be more common in sickle cell anaemia.

In this patient infection and dehydration clearly triggered a severe sickle cell crisis, which was exacerbated by the severe acidosis due to renal failure, sepsis, and tissue ischaemia. Although acute renal failure may be caused by septicaemia, the grossly raised creatine kinase activity, urinary findings, initial hypocalcaemia, and subsequent hypercalcaemia are typical of renal failure due to muscle necrosis (figure). Infection may provoke rhabdomyolysis but this is usually viral and rarely bacterial. ${ }^{3}$ In our patient the major pathogenic mechanism was probably muscle ischaemia induced by massive intramuscular sickling. Rhabdomyolysis has been reported in three patients with sickle cell trait. ${ }^{4}$ In each case, however, there was a clear history of abnormal muscle exercise, a recognised cause of muscle necrosis. We believe that sickle cell anaemia should be considered as an additional cause of non-traumatic rhabdomyolysis.

1 Grossman RA, Hamilton RW, Morse BM, Penn AS, Goldberg M. Non-traumatic rhabdomyolysis and acute renal failure. $N$ Engl $\mathcal{f}$ Med 1974;291:808-11.

Wintrobe MM. Clinical haematology. Philadelphia: Lea and Febiger, 1981:840. Kalish SB, Tallman MS, Cook FV, Blumen EA. Polymicrobial septicaemia associated with rhabdomyolysis myoglobinuria and acute renal failure. Arch

4 Intern Med 1982;142:133-4. rhabdomyolysis in sickle cell trait. Intensive Care Med 1979;2:204-5.

(Accepted 28 fanuary 1985)

Royal Free Hospital, London NW3 2QG

$S$ DEVEREUX, MB, MRCP, registrar in haematology

S M KNOWLES, MRCP, MRCPATH, consultant haematologist

Correspondence to: Dr S Devereux, Edgware General Hospital, Edgware, Middlesex.

\section{Accidental ingestion of sterilising tablets by children}

Accidental ingestion of caustic substances is common, ${ }^{1}$ particularly among children aged about two. Few patients develop severe sequelae -that is, oesophageal stricture-because generally the substance is not in contact with the mucosa for sufficient time to produce a burn, and any burns that are produced are not severe enough to result in stricture. ${ }^{2}$ As the exact time of ingestion is rarely known most patients are treated with early oesophagoscopy, steroids, and antibiotics. ${ }^{12}$

Sterilising tablets have been marketed in this country for the past 10 years, but as far as we know their accidental ingestion has not been reported previously. Even though they are wrapped in foil accidental ingestion is common: the National Poisons Information Service at New Cross Hospital received 119 calls about ingestion of sterilising tablets in the first eight months of 1984 . We report on two patients seen in our unit recently.

\section{Case reports}

Case 1-A 1 year old boy presented with sudden onset of vomiting after swallowing a sterilising tablet. He was crying persistently, was not cyanosed, and did not have stridor. Air entry to both lungs was good. Endoscopy showed slough on a swollen right aryepiglottic fold. The vocal cords, trachea, and oesophagus were normal. The child was treated with steroids, antibiotics, and humidification and was discharged two days later. Endoscopy six days after ingestion showed normal results, and he subsequently remained well.

Case 2-A 7 month old boy developed a cough, vomited copious amounts of clear fluid, and then became drowsy after swallowing a sterilising tablet. On admission he was cold and cyanosed with pronounced stridor. He had supraclavicular and subcostal recession and a tachycardia of 180 beats/min with irregular respiration. Owing to vomiting, spasm, and local oedema intubation was achieved only with extreme difficulty. The supraglottis and hypopharynx were grossly oedematous and ulcerated, precluding extubation 